\title{
Nyplatonsk politisk tenkning
}

Det antas ofte at det som står i tittelen her, er et ikke-eksisterende tema. I den store Cambridge History of Greek and Roman Political Thought fra 2000, redigert av Christopher Rowe og Malcolm Schofield, er politisk filosofi i nyplatonismen overhodet ikke et tema, og det samme kan sies om andre oversiktsverk som tar for seg antikkens politiske tenkning. Foruten noen korte forbigående bemerkninger her og der var det faktisk overhodet ingen som på alvor hadde kastet et blikk på nyplatonsk politisk filosofi inntil Dominic J. O’Meara kom med boken Platonopolis. Platonic Political Philosophy in Late Antiquity i 2003. ${ }^{1}$ Denne artikkelen henter mye fra O’Mearas bok og bygger på dens konklusjoner, men forsøker samtidig på en del punkter å ta diskusjonen videre. Det har vist seg at det faktisk finnes en god del politisk tenkning, til og med politisk filosofi, i de nyplatonske kildene. Og ikke bare teoretiserte nyplatonikerne om slike saker: I noen tilfeller fikk deres politiske filosofi et utslag i praksis som vi skal se på etter hvert.

Det er flere grunner til at man ikke har forventet å gjøre store funn av politisk filosofi hos nyplatonikerne. En grunn er at lite tyder på stor interesse i denne retning blant titlene til deres verker, både dem som er bevart og kjente titler på verker som er gått tapt. En annen og sannsynligvis enda viktigere grunn er at et bestemt bilde av den nyplatonske filosofen sitter ganske fast: Han eller hun er en person som fors $\varnothing$ ker å leve et liv i ånden blant de platonske ideer og nyte mystisk forening med det ubeskrivelige Ene, alle tings opphav; for det jordiske liv med sine lidelser, bekymringer og politiske virvar har filosofen kun likegyldighet, om ikke forakt. ${ }^{2}$ Det finnes nok flere tekster som kan trekkes frem som en bekreftelse på et slikt syn, men som jeg skal forsøke å vise, er det lett å feiltolke dem, og det finnes også indikasjoner på en ganske annen innstilling.

\footnotetext{
${ }^{1}$ Dominic J. O’Meara, Platonopolis. Platonic Political Philosophy in Late Antiquity. Oxford: Oxford University Press 2003.

${ }^{2}$ Det er en enda sterkere grunn enn i mange andre kontekster som angår antikkens filosofer, til å si «han eller hun» snarere enn bare «han». Det var flere profesjonelle kvinnelige filosofer blant nyplatonikerne i senantikken enn i noen tidligere skole, med et mulig unntak av pytagoreerne.
} 


\section{Hvem var nyplatonikerne?}

Det er noe kunstig ved å snakke om nyplatonismen som en klart avgrenset bevegelse innen antikkens filosofi. Denne termen ble konstruert av forskere tidlig på 1800-tallet for å karakterisere filosofien til Plotin (204/5-270) og andre som kom etter ham: Porfyrios (c. 235-c. 305), Jamblikk (c. 240-327), Proklos (412-485) og Damaskios (c. 458-538), for å nevne noe av de viktigste og mest kjente. ${ }^{3}$ Alle disse fulgte $\mathrm{i}$ hovedtrekk Plotins platonisme. Men ingen av dem så på seg selv som «ny» et eller annet: Tvert imot, de mente at de var helt fortrolige fortolkere av Platons tekster, som for dem nesten var å regne som hellige bøker. Det er på ingen måte åpenbart at nettopp disse platonikerne skiller seg mer fra mesteren enn mange andre som merkelappen «platoniker» har vært festet på. Dessuten er det åpenbart at tendenser i den retning som oppnår en moden form hos Plotin, var til stede hos hans forgjengere. Når man tar hensyn til at senere nyplatonikere (fra og med Jamblikk) avvek vesentlig fra Plotins lære, kan man godt spørre seg om Plotin nødvendigvis har mer til felles med dem enn forgjengere som Numenios (2. årh.).

Vi skal allikevel i det følgende akseptere fortolkningstradisjonen og godta termen «nyplatonisme» som en betegnelse på den hedenske Platon-inspirerte filosofi fra og med Plotin til slutten av hedendommen i det romerske riket. Denne retningen kan godt beskrives som et forsøk på å systematisere Platons lære. ${ }^{4}$ Som kjent skrev Platon dialoger hvor han aldri fremtrer i eget navn. Det følger av dialogens natur at Platons filosofi ikke blir systematisk fremstilt i hans verker. Aristoteles, stoikerne, og til og med epikureerne hadde laget filosofiske systemer som ofte ble fremstilt på et rimelig systematisk vis. Nyplatonikerne ønsket å gjøre noe lignende med Platon. Dette var derimot ikke en helt enkel oppgave. De gikk ut fra at dialogene Parmenides og Timaios inneholder hovedtrekkene i Platons system - ryggmargen i hele ontologien, for å si det sånn. Dette medfører at innfallsvinkelen til Platons tenkning er hans metafysikk og kosmologi. Etikk og politisk filosofi er underordnet metafysikken og kosmologien, og utlegges i lys av dem.

Plotins bilde av verden er hierarkisk og godt gjenkjennelig som platonsk selv om det avviker på en del punkter fra det som i dag er generelt akseptert som Platons lære: Tilværelsens øverste prinsipp er det Ene (også kalt det Gode), verdens første og

\footnotetext{
${ }^{3}$ Alle årstall her henviser selvfølgelig til «etter Kristi fødsel», hvis ikke annet blir nevnt.

${ }^{4}$ Om systematisering av Platon, se Georg Karamanolis, Plato and Aristotle in Agreement? Oxford: Oxford University Press 2006, særlig kapittel 1.
} 
$\emptyset$ verste prinsipp, et helt udifferensiert noe hinsides tanke og væren; dernest kommer et universelt intellekt som inneholder idéverdenen; deretter kommer sjelens nivå som inneholder både verdenssjelen og individuelle menneskelige sjeler. Sammen utgjør disse tre nivåene den intelligible verden. Den sansbare verden er også stratifisert: Vi har i hvert fall levende legemlige former som farge og figur, blotte legemer (romlige størrelser), og til slutt helt ubestemt stoff. Hierarkiet går fra det enkle og ene til stadig mer mangfold. Det representerer ikke bare et desinteressert syn på hva som finnes. Det Ene heter, som nevnt, også det Gode. Fra det Gode går ting nedover med hensyn til godhet og verdi. Vi mennesker, i hvert fall de fleste av oss, står forholdsvis lavt på verdiskalaen. Dette har selvsagt konsekvenser for både etikk og politisk tenkning. De senere nyplatonikere godkjente hovedtrekkene i dette bildet.

Det er viktig å huske at over 600 år adskiller Platon og Plotin, og at det skjedde mye i filosofien i mellomtiden. Nyplatonikerne tok opp en god del vokabular og delvis medfølgende doktriner fra stoikerne og ikke minst fra Aristoteles og hans skole. Faktisk mente alle nyplatonikere fra og med Porfyrios at det ikke fantes noen motsetning mellom Platon og Aristoteles, at sistnevnte faktisk var en platoniker. ${ }^{5}$ Det kompliserer bildet enda mer at særlig fra og med Jamblikk ble Pythagoras og hans skole ansett som en del av den autoritative arven, med den følge at tenkere som Jamblikk og Proklos var meget opptatt av matematikk og tallsymbolikk. Dette setter et tydelig preg på deres måte å lese Platon på, en måte som ofte kan virke fremmed for oss. Jamblikks forkjærlighet - besettelse, kunne man kanskje si - for tall og geometriske former får et utslag også i hans politiske tenkning. Jamblikk tenker seg for eksempel at det intelligible nivået, som er det umiddelbare forbildet for samfunnsordningen, er av matematisk karakter. Særlig mente han at geometriske proporsjoner som for eksempel 9:6=3:2 og den ulikesidede rette trekant uttrykker viktige samfunnsprinsipper: Den geometriske proporsjonen innebærer på det samfunnsmessige nivå Platons rettferdighetsformel i Staten (at enhver utøver den funksjon han eller hun er best egnet til), ${ }^{6}$ mens trekanten er et uttrykk for samfunnets harmoniske enhet ved at trekantens ulike sider er en modell for samfunnets klasser,

\footnotetext{
${ }^{5}$ Harmoniseringen av Platon og Aristoteles er et hovedtema i to nylige bøker: Lloyd P. Gerson, Aristotle and Other Platonists. Ithaca: Cornell University Press 2005 og Georg Karamanolis, Plato and Aristotle in Agreement?

${ }^{6}$ Se Jamblikk, Vit. Pyth., 30, 179 (finnes i engelsk oversettelse av Thomas Taylor, tilgjengelig her: https://classicalastrologer.files.wordpress.com/2012/12/iamblichus-the-pythagorean-life-1.pdf; Proclos, In Remp. I., 216, 21-217, 5; jf. Platon, Staten, 433b4. Staten finnes i norsk oversettelse i bind 5 av Vidarforlagets utgave av Platons samlede verker (Oslo 2001).
} 
deres harmoni og enhet: Klassene blir bundet sammen gjennom sine ytterpunkter hvor de møtes, og Pythagoras' ligning som sier at $\mathrm{a}^{2}+\mathrm{b}^{2}=\mathrm{c}^{2}$ (hvor a og b er trekantens korte sider, c den lengste), uttrykker deres harmoniske enhet. ${ }^{7}$

Et annet interessant aspekt ved nyplatonikerne fra og med Jamblikk, som også er relevant for deres politiske filosofi, er at religion har fătt en veldig sentral plass. (Plotin viste ikke noen stor interesse for tradisjonelle religiøse sedvaner og seremonier; han var med andre ord ikke en «tempelgåer».) $)^{8}$ Hos hans etterfølgere får ikke bare de tradisjonelle tolv olympiske guder, men også så å si alle tradisjonelle guddommer som ble dyrket i det enorme Romerriket, en plass i et metafysisk og kosmologisk system. Politisk sett er dette høyst relevant: De senere nyplatonikere aksepterte et flerkulturelt imperium med mange religioner og fors $\emptyset$ kte å inkorporere alle disse $\mathrm{i}$ et system som, ifølge dem, burde være akseptabelt for alle, selv om de tradisjonelle olympiske guder hadde den suverene plassen. Denne metafysikken og teologien skulle tjene som et lim i det flerkulturelle riket. Før kristendommens religiøse monopol i antikken var det ingenting i veien med å verdsette én guddom mer enn andre. Dette betød på ingen måte at andre guddommer ikke fantes.

Et annet faktum som også er relevant i vår kontekst, er at så å si samtlige nyplatonikere var overklassefolk med korte veier til den politiske makten i sine byer eller til og med i det romerske imperium. I Roma hadde Plotin et nært forhold til keiseren Gallienus (keiser fra 253-268) og hans kone, Salonina, som «beæret og beundret Plotin», skriver Plotins betrodde student, utgiver og biograf, Porfyrios. ${ }^{9}$ Blant hans regelmessige tilhørere var det flere senatorer, hvorav noen ble seriøse filosofistudenter. ${ }^{10}$ Jamblikk var av en gammel aristokratisk slekt i det velstående Syria. Etter å studert under bl.a. Porfyrios stiftet han sin egen skole i Apamea (omkring $100 \mathrm{~km}$ sør før Aleppo). Blant hans mange studenter var det en mann ved navn Sopater som ved Jamblikks død ble en sentral rådgiver for den kristne keiser Konstantin den store i Konstantinopel. If $\varnothing$ lge Evnapios, Sopaters biograf, fors $\varnothing$ kte han «gjennom fornuft $(\log \bar{o})$ å kontrollere og reformere Konstantins mål og drivkraft». ${ }^{11}$ Sopater ble innviklet i noen intriger ved hoffet og ble henrettet en gang før Konstantins død i 337. En annen av Jamblikks studenter, Evstathios, ble også en

\footnotetext{
${ }^{7}$ Se Jamblikk, Vit. Pyth., 27, 130-1; 30, 179 og Dominic J. O’Meara, op. cit., 102-105.

${ }^{8}$ Se Porfyr, Vita Plot., 10, 34-39. Porfyr

${ }^{9}$ Vita Plot., 12. Biografien henvises som regel til som Vita Plotini. Den fulle tittelen på norsk er Om Plotins liv og rekkefølgen av hans verker.

${ }^{10}$ Vita Plot., 7.

${ }^{11}$ Evnapios, Vita soph., 242. Oversettelsen her og av andre antikke kilder er artikkelforfatterens.
} 
keisermaktens tjener. Han ble i 358 sendt som imperiets ambassadør til det persiske hoffet. Ifølge den samme biografen, Evnapios, ble den persiske kongen Sapor så imponert av ham at han nesten var villig til å bytte sine regalier for filosofens kappe. ${ }^{12}$ En tredje student var Aidesios som etablerte sin egen skole i Pergamon. ${ }^{13}$ Han ble oppsøkt av den unge Julian (331/2-63, keiser Julian 361-63, kjent som «Julian den frafalne»). Vi skal senere se nøyere på Julians forhold til nyplatonismen. Selv på Proklos' tid, på 400-tallet, da kristendommen var temmelig godt etablert, stod Proklos nær den politiske makten i Athen hvor han levde og underviste. Marinos, Proklos' etterfølger og biograf, sier om Proklos' politiske virksomhet i Athen:

Han var med på møter hvor de overveide byens vel og ve, foreslo løsninger med stor praktisk visdom, diskuterte saker som har med rettferdighet å gjøre, med magistratene og nøydes ikke med å gi dem råd, men ville bruke filosofens talefrihet, med henblikk på å sørge for at de ga til enhver det han fortjener. ${ }^{14}$

Om en student, Arkiadas, sier Marinos, at Proklos

opplærte og trente ham i de borgerlige dyder og metoder, og som noen som heier på folk i en løpekonkurranse, oppfordret han ham til å stå foran alle andre i hans bys offentlige affærer og til å bli en privat velgjører til alle i samsvar med enhver form for dyd, men spesielt i samsvar med rettferdighet. ${ }^{15}$

Flere av dem som studerte under Proklos, ble profesjonelle filosofer, men mange andre ble viktige embetsmenn i sine byer eller til og med ved keiserens hoff. ${ }^{16}$

Denne korte oversikten burde holde for å gjøre oss mistenksomme overfor det tradisjonelle bildet av den senantikke platoniker som en person fullstendig uinteressert i denne verden og samfunnsspørsmål. Men hva hadde platonikerne å si? Hva var innholdet i deres politiske filosofi? Her er de bevarte kildene dessverre tynnere enn man skulle ønske. Likevel finnes det en del indikasjoner. Vi skal begynne med å se på Plotin, som muligens er den av de berømte nyplatonikerne som virker

\footnotetext{
${ }^{12}$ Evanpios, Vita soph., 465-6.

${ }^{13}$ Pergamon sto ved dagens Bodrum i sør-vest-Tyrkia.

${ }^{14}$ Vita Procli, 15)

15 Ibid., 14.

${ }^{16}$ Se Dominic J. O’Meara, op. cit., 21.
} 
minst interessert i samfunnsspørsmål. Deretter vil jeg gå nærmere inn på Jamblikk og Proklos sin politiske tenkning, for så å avslutte med en betraktning om keiser Julians platonisme.

\section{Plotin: hulen og solen}

Vi er så heldige at det er bevart Vita Plotini (Plotins liv), skrevet av hans betrodde student og redaktør, Porfyrios, hvor vi får et rimelig godt innblikk i Plotins person, oppfatninger og virke. Vi har også alle Plotins avhandlinger, utgitt av den samme Porfyrios i en samling som kalles Enneadene. ${ }^{17}$ Noen av disse, særlig Enneade I. 2, «Om dydene», og I.5., «Om lykken», viser Plotins holdninger til etikk. Det fremgår av både skriftene og biografien at Plotin ikke er særlig interessert i politikk eller politisk filosofi per se. Han sier svært lite om slike saker, og en fortelling fra Vita Plotini kan se ut til å bekrefte denne manglende interesse: Senatoren Rogatianus var blant Plotins tilhørere. Han kvittet seg med all sin eiendom og tjenere, til og med sitt eget hus, og opptok den filosofiske levemåte. Porfyrios sier at «Plotin satte stor pris på ham og fremstilte ham som et forbilde for praktiserende filosofer». ${ }^{18}$ Plotin hevder også selv at vismannen (ho spoudaios), som alene kan sies å være lykkelig, vil «gi avkall på myndighetsstilling og embete». ${ }^{19}$ Det ville allikevel være forhastet å slutte at Plotins filosofi er helt irrelevant for politisk tenkning. Men presist hvilke konsekvenser hans tenkning har på dette området, er en temmelig komplisert sak som vi skal se nærmere på.

Det finnes tre ulike teser om dydene hos Platon som Plotin forsøker å harmonisere i avhandlingen om dydene. I Staten blir de fire hoveddydene, visdom, mot, måtehold og rettferdighet, definert ut fra læren om sjelens tre deler: fornuft, temperament og begjær. Denne dydslæren forutsetter tilstedeværelsen av de tre sjelsdelene, og dydene blir hovedsakelig definert som fornuftens styre over hele sjelen med de ikke-rasjonelle delenes samtykke. I Faidon beskrives dyden som sjelens renselse av all påvirkning fra legemet. I samsvar med dette snakker Plotin om en slik

\footnotetext{
${ }^{17}$ Porfyr samlet og utga Plotins traktater i seks såkalte enneades (entall: enneas), hvor hver enneas inneholder ni traktater. Ordet enneas betyr «et sett av ni». Slik har vi 54 traktater av Plotin. Dette er likevel ikke helt i samsvar med den samling Plotin etterlot seg, fordi for å få frem dette tallet, måtte Porfyr dele noen avhandlinger opp. Han mente at tallet 54 var et særdeles godt tall fordi det er sammensatt av 2 og 3, dvs. $6 \times 3^{2}$ eller $3^{3} \times 2$. Ofte henviser man til Enneadene bare ved tall. For eksempel betyr «IV.4.27, 10» «fjerde Enneade, fjerde traktat, kapittel 27, linje 10».

${ }^{18}$ Vita Plot., 7, 44-47.

${ }^{19}$ «Om lykken», I.4.14, 20.
} 
dyd som «renselse», og vi vil innføre termen "katartisk dyd" for denne typen dyd (katharsis=renselse). Og i Theaitetos beskrives dyden som assimilasjon til gud (homoiôsis theôi). Hvordan kan disse tre formuleringene bli sett som aspekter ved ett og samme syn på dyden? Dette kan virke særlig problematisk gitt at gudene antakeligvis ikke har noen irrasjonelle sjelsdeler som må temmes og ledes, og det er derfor ikke lett å se hvordan en som er blitt assimilert med gud, skal kunne kontrollere irrasjonelle sjelsdeler eller rense sjelen for legemets påvirkning.

Plotins svar på dette er en lære om to eller tre grader av dyder: Lavest står det han kaller borgerlige dyder (politikai aretai). Disse dyder tilsvarer noenlunde dydene som beskrives i Statens 4. bok, som åpenbart er Plotins kilde her. ${ }^{20}$ Deretter kommer katartiske dyder, og på guddommens nivå står dydenes urbilder, som for eksempel rettferdighetens platonske idé. Disse er imidlertid ikke dyder, men noe hinsides dyd som dydene etterligner: Det er altså tre (eller fire) stadier av rettferdighet, men bare to (eller tre) stadier av dyder. Dydenes definisjoner som gis i Staten - rettferdighet er for eksempel det at hver sjelsdel gjør sin egen jobb og bare den - brukes mutatis mutandis på de høyere gradene. Slik blir rettferdighet på det katartiske nivået til sjelens aktivitet rettet mot intellektet. Ved dette, mener Plotin, utøver den rensede sjel sin egen funksjon. ${ }^{21}$

En person som har nådd de høyere stadier, må ha gått igjennom de lavere stadier og fremdeles ha de borgerlige dydene potensielt. Men dette gjelder ikke omvendt: Det er godt mulig å besitte de borgerlige dydene uten å ha de katartiske. ${ }^{22}$ La oss se nærmere på hva Plotin forstår med «borgerlig dyd». Dette uttrykket forekommer noen ganger hos Platon og ser ut til å henvise til den type dyd som først og fremst manifesteres i en borgers gode og lovlydige handlinger, uten at dypere filosofisk forståelse følger med. ${ }^{23}$ Plotin forstår også uttrykket slik. Det virker som enhver person som klarer å handle av fornuft og med fornuftens fullstendige kontroll

\footnotetext{
${ }^{20}$ Det er uklart om gradene er ment å være tre eller fire. Porfyr, som i Sententiae ad intelligibilia ducentes,32 adopterer og utvikler Plotins lære om grader av dyd, mener at det faktisk er to stadier i det Plotin kaller «katartisk dyd»: ett for den som er i prosess av renselse, et annet for den som har oppnådd den rene tilstand. Denne siste grad ble av senere platonikere kalt intellektuell dyd. Plotin har ikke ulike termer for dette, men man kan forstå hans tekst i I.2.4-5 slik at han faktisk tenker seg et skille. Se Eyjólfur K. Emilsson, Plotinus. London: Routledge 2017, 302.

${ }^{21} \mathrm{Se}$ «Om dydene», I.2.6, 18-19. En mer omfattende behandling av Plotins teori om dydene finnes for eksempel hos John M. Cooper, Pursuits of Wisdom. Six Ways of Life in Ancient Philosophy from Socrates to Plotinus. Princeton, N.J.: Princeton University Press 2012, kapittel 6.5 og, Eyjólfur K. Emilsson, op. cit., kapittel 10.

${ }^{22}$ I.2.7, 14-31.

${ }^{23}$ Se Forsvarstalen, 20b5-6; Protagoras, 223a1-b2, 224a1; Faidon 82a11; jf. også Staten 430c3.
} 
over sjelens irrasjonelle drifter, kan sies å ha «borgerlig dyd». Likevel er det en god grunn til å tenke at Plotin mener at borgerlig dyd knyttes særlig til politikere eller statsmenn. Han stiller spørsmålet om, og i så fall hvordan, borgerlig dyd kan anses som assimilasjon til gud. I sitt svar på dette spørsmål påpeker han at «tradisjonen hevder at borgerlig dydige menn er guddommelige, og på et eller annet vis ble de gjort slik i kraft av en slik dyd». ${ }^{24}$ Deres sjel har del i form og orden. Selv om de ikke har hevet seg opp til de høyere nivåer, holder dette til at de som kun besitter denne type dyd, på et vis sies å ligne på gud. Det er imidlertid klart at dette er den mest elementære form for etterligning av guddommen.

Hos Plotin knyttes borgerlige dyder særlig til politisk aktive mennesker, de som er opptatt av å styre og forbedre samfunnet. Men uttrykket kan også brukes om andre som viser klokskap og selvbeherskelse i sine handlinger. I Aristoteles' etiske og politiske filosofi, et felt Plotin var godt kjent med og gjorde utstrakt bruk av, er det samme slags tvetydighet: Det å besitte moralsk dyd innebærer å tenke og oppføre seg dydig i alle sammenhenger, men denne dyden knyttes likevel særlig til de som har ansvar for samfunnssaker, som om den får sitt mest storslåtte utslag der. Blant Plotins nyplatonske etterfølgere fantes det en diskusjon om oppdelingen av praktisk vitenskap i ulike arter: Deles den opp slik Plotins forgjenger, Alkinous (2. årh. e. Kr.; antakelig inspirert av Aristoteles), ${ }^{25}$ antyder, i politisk vitenskap rettet mot staten, $\varnothing$ konomi som er rettet mot husholdningen, og etikk rettet mot individet, eller bør vi heller si at det finnes kun én praktisk vitenskap som kan få utslag på ulike områder? ${ }^{26}$ Den mest vedtatte oppfatningen blant nyplatonikerne var at praktisk vitenskap egentlig er en og den samme, bare anvendt på forskjellige områder. Platon kan også tilskrives dette synet: I Statsmannen 259c sier han at det er én vitenskap for både husholdningen og staten og i Alkibiades 126d9-10 at samme kunst (technê) skaper samhold (homonoia) $\mathrm{i}$ individet og $\mathrm{i}$ samfunnet.

Et godt kjent tema fra antikkens politiske tenkning er spørsmålet om to typer liv, et politisk liv og et teoretisk (filosofisk) liv. Det er særlig Aristoteles som i Den nikomakiske etikkens tiende bok fremstiller disse som to gjensidig utelukkende alternativer, selv om heller ikke han nekter for, og faktisk sannsynligvis forutsetter, at filosofen må besitte de etiske dydene som utgjør statsmannens utmerkelse. Platon er

\footnotetext{
${ }^{24}$ I.2.1, 23-26.

${ }^{25}$ Alkinous, Didaskalikos, (Håndbok om platonisme), kap. 3.

${ }^{26}$ Se Dominic J. O’Meara, op. cit., 55-58.
} 
berømt for å ha et annet syn: I Staten argumenteres det for at samfunnets eneste håp er at filosofer får makten og anvender sin teoretiske kunnskap for å organisere og styre staten. Likevel er valget mellom et teoretisk liv og et politisk liv et aktuelt tema hos Platon også. Platons idol, Sokrates, virker stolt over ikke å mestre den talemåte og skikk som gjelder i samfunnsinstitusjonene, ${ }^{27}$ og han påstår at den indre stemmen som pleier å stoppe ham hvis han er i ferd med å gjøre noe galt, forhindrer ham fra å beskjeftige seg med politiske spørsmål. Han hevder til og med i samme kontekst at «det er nødvendig at enhver som på alvor kjemper i rettferdighetens tjeneste, gjør det som privatperson uten å blande seg i politikk - ellers vil han snart miste livet». ${ }^{28}$

Selv om Staten argumenterer for et filosofisk styre, er det heller ikke noen selvfølge i dette verket at filosofen blander seg i politikk. I hulelignelsen slipper en av fangene løs og kommer seg opp i lyset. Han nyter etter hvert sin tilværelse der. Allikevel vender han tilbake til hulen. Hvorfor? Filosofene i Kallipolis, den ideale stat, holder ikke bare på med å styre staten, de styrer og filosoferer i tur. Platon er veldig klar over at de helst ville slippe å styre og at det krever både overtalelse og tvang å motivere dem til å gjøre det. ${ }^{29}$ Det gis noen grunner som kan brukes for å overtale filosofene: Filosofene skylder samfunnet som har oppfostret dem så godt, denne tjeneste - dette er altså et spørsmål om rettferdighet - og de får dessuten lov til å bruke det meste av sin tid på filosofi uansett. Likevel er det fremdeles et av de omstridte spørsmål i Platon-tolkningen hvorfor filosofen går frivillig med på å stige ned. ${ }^{30}$ Det er klart at alternativet om å gi avkall er der, selv om den gode filosof nok innser at slik ting forholder seg, må han eller hun gjøre sin plikt i staten. Og når filosofen befinner seg i en dårlig stat uten realistiske midler til selv å ta makten, vil han føle seg maktesløs og unyttig, trekke seg unna og «holde på med sitt». ${ }^{31}$

Det følgende er kanskje en selvfølgelighet, men det er ytterst viktig ikke å glemme eller overse det: I Staten gir Platon det som en hovedgrunn for nødvendigheten av et filosofisk styre at filosofen som «stiger ned», vil forstå seg bedre på skyggene enn noen andre: «Og fordi dere har sett sannheten om hva som er edelt, rettferdig og godt, vil dere kjenne hvert skyggebilde for hva det er og også det

\footnotetext{
${ }^{27}$ Platon, Forsvarstalen, 17d-18a.

${ }^{28}$ Ibid., 31d-32a.

${ }^{29}$ Platon, Staten, 519c-520c; jf. samme 347c.

${ }^{30}$ En utmerket diskusjon av saken finnes hos Damian Caluori, "Reason and Necessity: the Descent of the Philosopher-Kings», i Oxford Studies in Ancient Philosophy XL, 2011.

${ }^{31}$ Se Platon, Staten, $496 \mathrm{c}-\mathrm{e}$.
} 
som det avbilder.» ${ }^{32}$ Dette sitatet er en del av overtalelsen som skal få filosofene til å gå tilbake ned i hulen. Substansen i det som sies her, er at ren teoretisk, filosofisk kunnskap har praktiske konsekvenser og kan anvendes i praksis. På dette punktet har Platon og Aristoteles ganske ulike syn. Ikke uforventet fulgte senantikkens platonikere Platon. Dette gjelder også Plotin som klart legger praktisk viten under den teoretiske (dialektikk): «På samme måte [som naturfilosofien] bygger den etiske viten på dialektikk ${ }^{33}$ i sin teoretiske del men tilføyer de dydige innstillinger (hexeis) og $\emptyset$ velser (askêseis) som fremkaller dem.» ${ }^{34}$

Det er i lys av betraktingene ovenfor at vi må se på Plotins eneste direkte henvisning til politiske konsekvenser av filosofisk innsikt. I «Om det Gode eller det Ene» (VI.9.) sier han med en temmelig klar allusjon til begynnelsen av Platons Lovene og hulelignelsen i Staten:

Etter å ha hatt samkvem med det Ene og, for å si det sånn, blitt tilstrekkelig familiær med det må [sjelen] tre til og formidle, hvis den kan, denne transcendente forening til en annen. Kanskje var det også på grunn av en slik forening at Minos ble kalt «Zevs godvenn», ${ }^{35} \mathrm{og}$ med tanke på dette nedsatte han lover som var avbildninger av dette samkvem, full som berøringen av det guddommelige hadde gjort ham av lovgivningstanker. Det hender også at sjelen finner politiske saker uverdige og foretrekker å forbli oppe; dette hender særlig dem som har sett mye. ${ }^{36}$

Slutten på denne passasjen kan bli forstått slik at Plotin trekker tilbake det han nettopp har sagt, og kommer frem til at egentlig er det mest naturlig for filosofen å forbli på det intelligible nivå. Men dette ville nok være en misforståelse. ${ }^{37}$ Plotins uttrykk «dette hender særlig dem som har sett mye» er visstnok noe kryptisk, men det han

\footnotetext{
${ }^{32}$ Platon, Staten 520c.

${ }^{33}$ Plotin og andre nyplatonikere forstår med «dialektikk» det samme som Platon generelt: Det er den høyeste teoretiske vitenskap som har ideene som sin gjenstand.

34 «Om dialektikk», I.3.6, 6-8.

${ }^{35}$ Fra Odysséen IXX, 178-179. Plotins kilde kan godt være den pseudo-platonske dialogen Minos, 318e-320d eller, noe som er mest sannsynlig, begynnelsen av Platons Lovene, hvor det sies at kreterne så Zeus som sin lovgiver siden deres legendariske konge, Minos, hvert niende år skal ha hatt samråd med Zeus. For Plotin står Zeus her for det Ene.

${ }^{36}$ VI.9.7, 20-28.

${ }^{37}$ Denne passasjen blir grundig diskutert hos Dominic J. O’Meara, op. cit.,, 74-75 og Suzan SternGillet, «Plotinus on Metaphysics and Morality», i Pauliina Remes og Svetla Slaveva-Griffin (red.), The Routledge Handbook of Neoplatonism. London: Routledge 2015, 413.
} 
sikkert mener, er at folk som har sett mye av vår sansbare verden og av den grunn blir skremt fra å påta seg en politisk rolle, ikke ser for seg at de kan være av nytte. Det er ikke slik, heller ikke ifølge Platon, at filosofen påtar seg en politisk rolle i enhver kontekst, tvert imot. ${ }^{38}$ Plotin tenker ikke her på noen som har sett så mye av den intelligible sfære at han eller hun ikke kan tenke seg å forlate den, men heller på noen som har sett så mye mislykket politikk at han eller hun vet at muligheten for å gjøre noe godt ikke finnes.

La oss bemerke også angående denne passasjen at på tross av sine noe skeptiske uttrykk vi har sett om verdigheten av et politisk liv, stiller Plotin seg her positiv til at teoretisk kunnskap - i dette tilfellet faktisk noe mer enn teoretisk kunnskap, nemlig samkvem med det Ene, som strengt tatt er hinsides kunnskap - kan omsettes til gode lover for samfunnet. Dette skjer ved imitasjon. Platonsk imitasjon innebærer alltid et tap og slik er det også i dette tilfellet: Det er ikke slik at det Ene selv, det uutsigelige, transcendente opphav til all væren, trekkes ned på jorden. Det som blir igjen i Minos’ sjel av erfaringen av dette, som han fors $\varnothing$ ker å videreføre til lovene og samfunnet, er etterligninger, noe som bevarer noen viktige preg av det Ene, men likevel kommer til kort ved sammenligning med det.

Men hvordan blir man fylt opp med gode og fornuftige lover gjennom samkvem med det Ene? Plotin gir ikke noen nærmere forklaring, men svaret er sikkert at dette skjer ved at filosofen blir dydig, guddommeliggjort. Det finnes analoge passasjer i Staten som kaster lys over hvordan Platon tenker seg dette. Det er meget sannsynlig at Plotin har disse passasjene i bakhodet her. En slik tolkning ville også være godt i samsvar med avhandlingen om dydene (I.2) og den om lykken (I.4). Som før bemerket heter Plotins det Ene også det Gode, og en av hovedkildene for dette virkelighetens første prinsipp hos Plotin er det Godes idé i Staten. Dette betyr at den som har hatt samkvem med det Ene, er i samme stilling som fangen som har steget opp fra hulen og klart å se solen. ${ }^{39}$ En annen passasje, en del av samme diskusjon i Platons Staten, beskriver i noen få vendinger hvordan filosofen som har hatt samkvem med ideene, blir i utmerket stand til å organisere samfunnet og andres sjeler på et fornuftig vis. Sokrates sier her at filosofen som

\footnotetext{
${ }^{38}$ Se Platon, Staten $496 \mathrm{c}-\mathrm{e}$.

${ }^{39}$ Ibid., 516b-c.
} 
fester sitt blikk og ser og beskuer ting som er ordnet og alltid ved det samme, ting som verken gjør urett eller lider den, siden de alle er rasjonelt ordnet; han imiterer dem og forsøker å bli så lik dem som han makter. Eller tror du at noen kan ha samkvem med ting han beundrer uten å imitere dem? [...] Da vil visdomselskeren som har samkvem med guddommelige og ordnete ting, selv bli så guddommelig og ordnet som noe menneske kan bli. ${ }^{40}$

Og litt senere sier han at

hvis en eller annen nødvendighet får ham til å bry seg om å installere det han ser der i menneskenes karakter, både som borgere og privatpersoner, istedenfor å forme bare seg selv, tror du han vil bli en dårlig produsent av måtehold, rettferdighet og andre former for borgerlig dyd ${ }^{41}$

Sokrates fortsetter så med å beskrive hvordan visdomselskeren, dvs. filosofen, vil bruke det han har lært, for å trekke hovedlinjene i statsforfatningen (to schêma tês politeias) som en maler som har et forbilde og materialer til å arbeide med, vil forme et samfunn og borgere som er så gode som materialene tillater. ${ }^{42}$

Filosofen vil altså først forme seg selv med ideene som modell - vi bør i denne forbindelse huske at det er det Godes idé som gir de andre ideene sannhet og intelligibilitet $^{43}$ - og siden former han eller hun de andre borgerne og samfunnet. Verken Platon eller Plotin er helt tydelige på hva presist filosofen bruker som modell i formgivingen av borgerne og samfunnet. Passasjen vi henviste til hvor filosofen sammenlignes med en maler, blir som regel tolket slik at filosofen ser opp til selve ideene som modeller. Det er allikevel ikke nødvendig å tolke den slik: Platon sier at filosofen ser på det som «av naturen er rettferdig, skjønt, og måteholdent». Dette kunne godt henvise til trekk filosofens egen sjel har fått gjennom sitt samkvem med ideene, snarere enn til selve idéverdenen direkte. I en tidligere publisert artikkel har jeg argumentert for at både for Platon og Plotin er den umiddelbare modellen for

\footnotetext{
${ }^{40}$ Ibid., 500b8-d1.

${ }^{41}$ Ibid., 500d4-8.

${ }^{42}$ Platon, Staten 501a9-c2.

${ }^{43}$ Platon, Staten 509b5-10.
} 
handling på sjelens nivå, et nivå som, hvis alt går riktig for seg, tar modell av ideene. $^{44}$

Uansett hvordan dette måtte forholde seg, så antyder Platon i denne passasjen ikke noen indre grunn hos filosofene til å stige ned i hulen igjen. Som vi så, snakker han her om det eventuelle tilfelle at «en eller annen nødvendighet får ham til å bry seg». Selv om vi aksepterer grunnen Platon eksplisitt gir i Staten, at filosofene ville innrømme at de skylder samfunnet dette, at noe annet ville være urettferdig, så er ikke dette helt godt nok: Beslutningen om å stige ned presenteres som et offer, noe filosofene helst ville unnslippe. Selv om Staten riktig nok argumenterer for at det ikke finnes noen konflikt mellom rettferdighet og lykke, og at rettferdighet faktisk er en forutsetning for et lykkelig liv, er det ikke åpenbart fra hulepassasjen at filosofene blir lykkeligere enn de ellers ville ha vært ved å stige ned i samfunnet. Tvert imot. For nyplatonikere som Plotin ville et utilitaristisk argument som hevder at filosofen burde stige ned fordi han eller hun ellers ville risikere å bli styrt av dårligere mennesker og derved blir mindre lykkelig, ikke veie tungt: Ens lykke eller ulykke er uavhengig av ytre omstendigheter som et dårlig styre. Plotin er nok påvirket av stoisk tenkning på dette punktet, men det finnes mange passasjer hos Platon som også kan trekkes frem til støtte for en slik holdning. ${ }^{45}$

Finnes det hos Platon noe tydelig svar på spørsmålet om hva som beveger filosofene til å gå ned igjen? Jeg har i sikte et svar som ville vært akseptabelt for Plotin og eventuelt de andre nyplatonikere. Faktisk finnes det en god del i andre passasjer hos Platon som de senantikke platonikerne kunne bruke for å støtte sin tolkning av fangens motivasjon. Plotin sier at Minos er blitt fylt med noe på grunn av samkvemmet med det Ene, og jeg har tolket dette slik at han derved blir dydig. Platon bruker selv lignende metaforer for å beskrive resultatet av filosofens samkvem med ideene, selv om hans språk er til tider mer eksplisitt erotisk enn Plotins her: Filosofen blir ikke bare «oppfylt», men til og med «gravid»-«barna» som resulterer fra

\footnotetext{
${ }^{44}$ Eyjólfur K. Emilsson, «Plotinus and Plato on the Soul and Action», i Rachel Barney, Tad Brennan og Charles Brittain (red.), Plato and the Divided Self. Cambridge: Cambridge University Press 2012. Grunnlaget for denne tolkning av Platon er særlig Staten 443c-444a og 592a. For Plotin, se III.8.4-6 og VI.8.6, 19-24.

${ }^{45}$ Det kan godt sies at det er en av Statens hovedkonklusjoner at dyd ikke bare er en nødvendig, men også en tilstrekkelig betingelse for et lykkelig liv. Det følger av dette at en person som er rettferdig, men antas å være urettferdig og lider på grunn av denne antakelsen (jfr. Staten 260e-361d), til tross for dette kan være lykkelig. Denne konklusjonen trekkes i slutten av 4. bok, og så endelig i den 10. og siste boken på 612c-613b. Dette tema er også gjennomgående i Gorgias.
} 
graviditeten, er sann dyd. ${ }^{46}$ Denne metaforen antyder, selv om det ikke sies eksplisitt, at det hos filosofen oppstår en slags lyst eller et ønske om å videreføre det han eller hun har lært. En annen relevant tekst i denne sammenheng er Timaios, 29e1-30a, hvor det sies at på grunn av sin godhet og ugjerrige natur skapte demiurgen en verden som var så god og lik ham selv som en skapning kan bli. Demiurgen ønsket faktisk (eboulêthê) å skape en god og vakker verden. Demiurgen og hans skapelse av verden tjente selvsagt som en modell for de senantikke platonikere for hvordan filosofer oppfører seg: Å bli gjort guddommelig betyr å bli lik guddommen, og det er naturlig å anta at dette innebærer å ha samme slags $\phi n s k e$ som guddommen. Filosofen vil da $\emptyset$ nske å skape orden og harmoni: Han forsøker å gjenskape det guddommelige her på jorden. Proklos, for eksempel, uttrykker dette slik:

Fordi det som er helt godt, har sin fullbyrdelse ikke bare ved å oppbevare seg selv, men ønsker ved å gi over til andre og fritt for gjerrighet å forsyne det med godhet og gjøre det lik seg selv. ${ }^{47}$

Denne passasjen gjelder sjeler som ikke stiger ned fra den intelligible sfære, men som allikevel utøver forsyn for det som er satt under dem. Samme prinsipp gjelder også på lavere nivåer, til og med det politiske:

Dette er analogt med det politiske menneske: Det er klart at det starter fra kunnskap og utforskning, og da, på denne måten, ordner det hele staten og viser i praksis konklusjonene som er trukket fra denne kunnskap. Slik kjenner også elskeren sin kjærlighetsgjenstand, hvilken klasse den tilhører, og da gir han den en del i sin forsynsfulle omsorg. ${ }^{48}$

Proklos' siste bemerkning her om forsynsfull omsorg fører oss til andre steder hos Platon som for nyplatonikerne utgjorde belegg for filosofenes samfunnsrolle og generelt engasjement overfor det som er satt under dem: Det er begrepene om omsorg og forsyn. Et viktig slikt sted, som Plotin siterer en del ganger, er Faidros, 246b: «Sjel

\footnotetext{
${ }^{46}$ Se Symposion, 212a og Staten, 490b.

${ }^{47}$ Proklos, De malorum subsistentia 23, 21-5. Se også Dominic J. O’Meara, op. cit., 76.

${ }^{48}$ Proklos, In Alcibiadem 95, 19-25.
} 
i sin helhet har omsorg (epimeleitai) for alt som er uten sjel.» ${ }^{49}$ Den grunnleggende tanken her og i den nyplatonske tolkningen av de andre Platon-passasjene som er anført her, er at kunnskapen om de høyere prinsipper skaper et slags ønske i sjelen til å formidle det den har lært på et lavere nivå.

Gitt det som nå er blitt sagt, finnes det hos Plotin en vei opp fra hulen, som tilsvarer det han og andre nyplatonikere (og som vi så også Platon selv) kaller guddommeliggjøring, og også en vei ned. Filosofen som er blitt dydig og guddommelig, kan, og muligens på et vis ønske - gå ned igjen. Dette vil få utslag i praksis. For mange vil det sikkert først og fremst vise seg i klok og riktig oppførsel på et hverdagslig områd,e slik Plotin viste ifølge Porfyrios’ Vita Plotini: Han fremstiller Plotin slik at selv om han levde helt og holdent $\mathrm{i}$ ånden, var han praktisk klok, til og med oppmerksom på ting andre ikke merket. ${ }^{50}$

Et interessant trekk ved Plotins handlingsetikk er at selv om filosofen vil utføre de riktige og passende handlingene i enhver situasjon - som dommer vil han dømme rettferdig, som general vil han vise mot, og så videre - er det ingenting som tyder på at filosofen har noen lyst eller annen motivasjon for å havne i roller som krever en bestemt type handling. Dette gjelder også politisk virksomhet. Ingenting antyder at en filosof har noen lyst eller en plikt til å oppsøke situasjoner hvor hun kunne bli til nytte i samfunnet. Selv om det er grunner for å mene at det oppstår et generelt ønske hos filosofen om å ordne opp i den ofte kaotiske sansbare verden, ser det ikke ut til at nyplatonikerne så på det som sin oppgave å lete etter uorden for å rydde opp i den. Men hvis filosofen skulle havne i en slik situasjon, vil hun gjøre det som situasjonen krever, til og med bli romersk keiser med alle de gjøremål som dette innebærer. Filosofen vil til og med ha en teori om hvordan en slik oppgave bør gjennomføres. Vi skal se nærmere på nettopp et slikt tilfelle i slutten av denne artikkelen.

Denne forholdsvis passive holdning som nettopp har vært beskrevet, kan virke underlig av flere grunner: Hvis filosofen har lyst og evne til å ordne opp, hvorfor gjør han ikke mer? Svaret på dette vil nok være både spekulativt og uavklart. Det er lett å tenke seg at Platons bemerkning i Theaitetos, 176a, at «onder kan aldri bli utryddet

\footnotetext{
${ }^{49}$ Se Plotin II.9.18, 39-40; III.2.4, 9; IV.3.1, 31-34; For «omsorg» hos Platon, se Forsvarstalen, 29de, 36c, Alkibiades I, 128b8-9, Staten, 412c; jf. også Plotin VI. 7. 26, 11-12; IV. 3. 17, 28 og I. 4.14, 19. ${ }^{50}$ Porfyr beretter flere anekdoter som viser Plotin i et slikt lys. Den mest bemerkelsesverdige er kanskje en som angår Porfyr selv: Han led av et tungt sinn og hadde tanker om å ta sitt eget liv, men hadde ikke fortalt noen om dette. En dag dukker Plotin plutselig opp i hans hjem og sier at «denne lyst på døden stammer ikke fra noen rasjonell beslutning, men fra en melankolsk disposisjon, og oppfordret meg til å reise på ferie» (Vita Plot. 11, 14-16). Porfyr reiste til Sicilia og ble kvitt disse tanker.
} 
[...] og de må for alltid sveve over vår dødelige natur og region her» spiller en rolle her. Det kan ikke være snakk om å skape noe vedvarende paradis fritt for ondskap her på jorden. Hvis man i tillegg mener at det viktigste her i verden ikke er hvordan den ustabile sansbare sfære utfolder seg, men hvordan man tar vare på sin sjel - det eneste som i streng forstand står i vår makt - så er det kanskje ikke noe rart at filosofen ikke ser på det som sin primære oppgave å søke opp ondskapen og bekjempe den: Den kampen er på et vis tapt på forhånd, og det finnes uansett viktigere oppgaver. Men filosofen vil ikke nøle med å gjøre det som situasjonen krever og står i hans makt der og da hvor hun befinner seg.

Vi kan oppsummere det vi er kommet frem til. På et eksplisitt plan er det lite politisk tenkning å finne hos Plotin. Det som tross alt finnes, er helt i samsvar med synet i Platons Staten, hvis vi ser bort fra Platons iver etter en stat styrt av filosofer et punkt som nok utgjør en betydelig forskjell mellom de to. Det å delta i politikk er ifølge Plotin ikke noe som i seg selv er ønskelig for en filosof, og de fleste gjør nok best i å la være. Men det er heller ingenting som i prinsippet utelukker filosofens deltakelse. Om en filosof burde gjøre dette, kommer nok an på omstendighetene $\mathrm{i}$ samfunnet. Hvis omstendighetene stemmer, er filosofens sjel fylt med ideer som kan igangsettes for å gjenspeile den guddommelige ordning slik det lar seg gjøre på et menneskelig nivå.

\section{Jamblikk og Proklos' politiske tenkning}

De grunnleggende temaene som vi har nevnt hittil, oppstiging, guddommeliggjøring og nedstiging, er også sentrale temaer for nyplatonikerne etter Plotin, selv om det skjer en del endringer. Disse tenkerne var svært opptatt av å sette alt i «riktige bokser». De var skolastiske og systematiske på en måte Plotin ikke var. Vi ser denne tendens allerede i Porfyrios' organisering av hans utgave av Plotins traktater: Den bygger på en idé om vitenskapenes hierarki, hvor praktisk viten blir fremstilt som den mest elementære, fulgt av fysikk og kosmologi, dernest sjelen og til slutt intellektet og det Ene.

Jamblikk og Proklos førte denne skolastiske tendensen til nye høyder. Den førstnevnte knyttet dette hierarkiet av vitenskaper systematisk til dydenes hierarki og til et bestemt studieopplegg som ble stående lenge for lesningen av Aristoteles, Platon 
og andre autoritative tekster. ${ }^{51}$ Dette studieløpet var designet for blivende filosofer og samfunnsledere. Dette fremstilles her for at vi kan se hvilken plass praktisk, og særlig politisk, filosofi får i dette studieløpet. Studentene ville først lese noen oppbyggelige tekster som de pseudo-pytagoreiske Gyldne vers og stoikeren Epiktets Håndbok. Dette var for å skape en riktig innstilling hos dem. Så fulgte et grundig studium av Aristoteles som kulminerte med lesning av Metafysikken. Deretter kastet man seg over Platons dialoger i to sykluser som kulminerte med lesningen av Parmenides og Timaios. $^{52}$

Studieløpet i borgerlig dyd og praktisk vitenskap var meget omfattende dagens studenter ville sikkert ha klaget hvis de ble forelagt et så stort pensum med vanskelige tekster. Man begynte som allerede nevnt med innledende stoff som skulle inspirere studentene og sette dem på riktig kurs. Fra Aristoteles ble særlig Den nikomakiske etikk lest (et verk som Aristoteles selv beskriver som en politisk vitenskap på 1094a27), men også Politikken, og de andre etikkene i tillegg til Økonomien og Konstitusjoner. Av Platon leste man Forsvarstalen, Alkibiades, Gorgias, Staten og Lovene. Det er ikke noen tilfeldighet at mange av de kjente nyplatonske kommentarer tar for seg nettopp de verker som her er nevnt, i tillegg til andre verker av Aristoteles som også utgjorde en del av pensum. Også Plotins første Enneade, som ifølge Porfyrios handler om etikk, ble lest, samt pytagoreisk politisk vitenskap slik den presenteres i Jamblikks Om pythagoreisme..$^{53}$

Antakelig tok en del av studentene kun denne tidlige, praktiske delen av studiene. Av grunner som vi skal se, mente man ikke at en aspirerende filosof nødvendigvis måtte ha oppnådd den høyeste form for dyd for å stige ned og gjøre nytte av seg i samfunnet. Proklos, som selv var opptatt med «høyere saker», oppfordret sin nære medarbeider, Arkiadas, til å gå i politisk retning:

[Proklos] opplærte ham og trenet ham i de borgerlige dyder og metoder og, som man heier på folk i kappløp, oppfordret han ham til å stå i fronten av offentligheten i sin by og til privat å være en velgjører til alle ifølge enhver type dyd, men rettferdighet i særdeleshet. ${ }^{54}$

\footnotetext{
${ }^{51}$ Om studieløp i senantikken, se også Harold Tarrant, «Platonist Curricula and Their Influence», i Pauliina Remes og Svetla Slaveva-Griffin (red.), op. cit.

${ }^{52}$ Det som her sies om studieløp, er basert på Dominic J. O’Meara, op. cit., 62-68.

${ }^{53}$ Se ibid., 68.

${ }^{54}$ Marinus, Vita Procli, 14. Se Dominic J. O’Meara, op. cit., 20.
} 
Det at den filosofisk utdannede politiske lederen ikke nødvendigvis selv har oppnådd den høyeste form for dyd, henger sikkert sammen med et bemerkelsesverdig trekk ved den politiske filosofien til Jamblikk, Proklos og andre rundt dem: Ganske bevisst tar de ikke bare Staten, men også Platons Lovene som en autoritativ tekst i politisk filosofi. I Lovene er lederne ikke nødvendigvis filosofer, selv om de i en viss forstand må være vise. I moderne tid har det vært vanlig å se på forholdet mellom disse to verkene slik at Platon, skuffet over sine mislykkede forsøk på ambisiøs politisk reform à la Staten i Syrakus, fors økte seg i sin godt modne alder på et nytt, mer moderat filosofisk-politisk prosjekt, nemlig det som beskrives i Lovene. Jamblikk, Proklos og deres etterfølgere så annerledes på saken. De identifiserte forholdet mellom Kallipolis, den ideale stat som beskrives i Staten, og Lovenes stat med det som i Lovene, $39 \mathrm{~b}$-e beskrives som forholdet mellom den beste statsforfatning og den nest beste. De senere nyplatonikerne mente at Kallipolis er en stat for «guder og gudebarn» (jf. Lovene, 739e). Den er altså ikke en stat som det er realistisk for vanlige mennesker å etablere. Dette betyr at Kallipolis har en status som et guddommelig ideal som lavere statsformer kan imitere på et vis, men på grunn av omstendigheter og menneskelig natur må selv den nest beste statsformen fire på kravene og tillate for eksempel privat eiendom og et overveldende mannlig styre. ${ }^{55}$

Det er lett å se på dette kompromisset som simpelthen et uttrykk for en realisme hos de nyplatonske intellektuelle. Det kan allikevel godt tenkes at det også er en sosial grunn for denne satsingen på Lovene. Som tidligere skildret var disse nyplatonske tenkerne og deres studenter i det romerske riket fra det 3. til det 6 . århundre i nærheten av maktens korridorer, om de ikke likefrem stod i dem. De var som tidligere nevnt overklassefolk i noe som må ha virket som en stabil stat, ikke minst i den sørlige og sentrale delen. På tross av sin filosofiske idealisme ernærte de ikke noen tanker om grunnleggende samfunnsendringer. Dette betyr allikevel ikke at de ikke hadde ideer om reformer, grunnet i deres filosofiske tenkning, som de ønsket å iverksette og la prege samfunnet slik det siste sitatet fra Marinus også antyder.

\section{Flavius Claudius Julianus Augustus, kalt «Julian den frafalne»}

\footnotetext{
55 Jf. Proklos, In Remp. I, 161 14-163, 9.
} 
Det finnes flere tekster som ikke er skrevet av de best kjente filosofene, men som stammer fra deres krets og uttrykker Platon-inspirert politisk tenkning. Den mest bemerkelsesverdige av disse tenkerne er uten tvil Julianus, romersk keiser fra 361-63. Julianus eller Julian var nevø til keiser Konstantin «den store» (272-337), som hadde akseptert og promotert kristendommen i Romerriket. Konstantin ble etterfulgt av sin sønn, Konstantius II, keiser fra 337-361. Konstantius II var farlig for sine slektninger: Han fikk flere av dem henrettet, bl.a. Julians halvbror. I sin oppvekst ble Julian holdt unna keiseren fordi det var fare for hans liv. Da han senere var blitt nærmeste tronarving, ble han utnevnt «Caesar» i Vesten og bodde i Gallia hvor han viste seg som en dyktig hærfører. ${ }^{56}$ Omsider erklærte hans soldater Julian til keiser etter at han hadde nektet å gi støtte til Konstantius’ felttog mot perserne. Det så ut til å bli et slag mellom Julian og Konstantius, men den sistnevnte døde på veien til slaget, og Julian ble utnevnt til keiser. ${ }^{57}$

Julian fikk en kristen oppvekst, men ble i ung alder interessert i nyplatonsk filosofi og tradisjonell religion. I Pergamon oppsøkte han en av Jamblikks studenter, Aidesios, som hadde etablert sin egen skole der, for å lære mer filosofi enn han hadde klart på egenhånd. Aidesios, som var blitt gammel, henviste ham til sine studenter. Særlig tre av disse, Maximus fra Efesos, Krysanthios og Priskos, ble viktige for ham. ${ }^{58}$ Julian etterlot seg en god del skrifter: taler, brev, og hymner. Det finnes ikke noen fagfilosofisk traktat av ham. Da han var blitt keiser, fors økte Julian å gjenopprette den tradisjonelle hedenske religionen i keiserdømmet. Det er ikke riktig at han forfulgte de kristne slik det ofte blir antatt, men han fratok dem privilegier som de hadde oppnådd. Det kan se ut som om hans mål var å utrydde eller i hvert fall dempe kristendommens innflytelse blant overklassen og rikets embetsstand, og forvise kristendommen tilbake til de fattige. Ellers sørget han for religionsfrihet i sin keiserperiode med sitt toleranseedikt i 362, hvor også kristne «kjettere» som hadde vært forvist, ble tillatt sin tro.

O'Meara argumenterer overbevisende for at Julians nyplatonisme generelt har vært undervurdert i historikeres tolkninger av ham som person og som sosial

\footnotetext{
${ }^{56}$ På denne tiden betød tittelen «Caesar» at innehaveren var utpekt til å overta som keiser. Ordet «keiser»stammer selvsagt fra «Caesar», som i sin tur stammer fra Julius Caesars navn. Men keiseren het «imperator» på latin.

${ }^{57}$ Julians liv er interessant av flere grunner, og det er også hans kompliserte karakter. Dette er sikkert grunnen til at han trer frem i flere litterære verk: Ibsens Keiser og Galileer fra 1872 handler om ham; det gjør også en berømt historisk roman av Gore Vidal, Julian, fra 1964 og flere andre litterære verker. ${ }^{58}$ Se Polymnia Athanassiadi, Julian. An Intellectual Biography. London: Routledge 1992, 32-39.
} 
reformator. ${ }^{59}$ Den klareste bekjennelsen til nyplatonsk filosofi finnes i hans Hymne til Helios, som tolker Platons sollignelse i Staten på nyplatonsk vis og gir en filosofisk beskrivelse av den hedenske gudeverden i samsvar med Jamblikks syn. ${ }^{60}$ Hans politisk-filosofiske tenkning blir ikke systematisk presentert i de bevarte skrifter. Det er allikevel mulig å få en viss innsikt $\mathrm{i}$ hans tenkning om slike saker ut fra hans etterlatte verk og handlinger. Det påfallende er vekten han legger på religion og fromhet - på hedensk vis selvsagt, de kristne var ifølge ham ateister. Denne vektleggingen skyldes uten tvil at Julian var en troende mann, endatil med en tro dypt påvirket av temmelig abstrakt filosofi. ${ }^{61}$ Som andre nyplatonikere mente han at det er innlysende for fornuften at det finnes guder, og at de styrer verden. Respekt for gudene er derfor påkrevet av fornuftsgrunner. Denne respekten var allikevel ikke noen privatsak: Samfunnets ve og vel stod på spill, og åpenbart så Julian på fromhet som en borgerlig dyd. Et velfungerende samfunn trenger fromhet som er uttrykt både individuelt og sosialt.

Av denne grunn la Julian stor vekt på presters plettfrie karakter og utdanning og foretok en radikal reform av prestestanden. ${ }^{62}$ En prests karaktertrekk burde være to philotheon kai philanthropon, «en vennlig innstilling til guder og mennesker». ${ }^{63}$ Allerede Porfyrios hadde antydet, og Jamblikk insistert på, at presten og filosofen er én og samme person. ${ }^{64}$ Julian satte denne doktrinen ut i livet. Han forsøkte å etablere et hierarki i presteskapet (igjen inspirert av Jamblikk), hvor han selv var høyeste prest, pontifex maximus, mens alle hans umiddelbare regionale underordnede prester var nyplatonske filosofer. Disse ville så i tur utpeke sine underordnede på et vis som gjenspeiler nyplatonsk lære om emanasjon.

Mye i Julians syn på religionens rolle i samfunnet er i godt samsvar med Platons program i Lovene. Julian så ikke på seg selv som en guddommeliggjort filosof, i hvert fall ikke på høyeste trin. Hans program ligner mye mer på det man ser i Lovene enn i Staten. O’Meara siterer flere likhetstegn: (1) Programmet er konservativt i sitt vesen, slik det er også i Lovene: Antikke tradisjoner skal ikke forstyrres. Dette forklarer for

\footnotetext{
${ }^{59}$ Polymnia Athanassiadi viser likevel god forståelse for viktigheten av den nyplatonske filosofi for Julian, selv om hennes redegjørelse mangler dybden til O’Mearas arbeid.

${ }^{60}$ Hymnen til Helios og andre bevarte skrifter av Julian finnes i Wilmer Cave Wrights engelske oversettelse i Loeb-serien: Harvard University Press 1913-1915 (3 bind).

${ }^{61}$ Se for eksempel Julians Hymne til kong Helios.

${ }^{62}$ Om Julians reform av prestestanden, se Polymnia Athanassiadi, op. cit., 181-189.

${ }^{63}$ Julian, Brev, 89b til Theodor. Julian hadde utnevnt denne Theodor, en filosof, til høyesteprest av Asia.

${ }^{64}$ Porfyr, Abst., II. 3, 49; IV. 6-8; Jamblikk, De myst., I.3.
} 
eksempel Julians positive holdning til jødedommen i motsetning til kristendommen.

(2) Lokale guder har sin rettmessige plass hos Julian. Som O’Meara bemerker:

Hvis de lokale gudene i Lovene er integrert i et sentralisert system i bystaten med Akropolis’ guder i presidiet, så er de i Julians keiserdømme til stede som guder tilhørende forskjellige folkeslag og regioner underordnet de høyeste guddommer i den greske tradisjon, guddommer som tilsvarer hovedprinsippene i et sen-nyplatonsk metafysisk hierarki. ${ }^{65}$

Julian ønsket seg et uforstyrret filosofisk liv, ikke å bli hærfører eller keiser. ${ }^{66}$ Han er et eksempel på en filosof som uventet befant seg med makt og handlingsrom. Hans opprinnelse, omstendighetene og tilfeldighetene gjorde at han ble keiser i det enorme riket. I et svært bemerkelsesverdig brev til filosofen og retoren Themistios gjør Julian det klart at han ser på det kontemplative livet som suverent, selv om han er blitt keiser og tar det ansvaret for handling som følger med det. ${ }^{67}$ Themistios hadde oppfordret den nye keiseren til å foretrekke handling fremfor filosofisk kontemplasjon. Han tilbød Julian sine tjenester, men Julian takket nei og ikke uten sarkasme rådet han Themistios til å gå tilbake til sine bøker siden det kontemplative livet er edlere enn det praktiske. $^{68}$

\section{Konklusjon}

Det virker rimelig å konkludere denne oversikten over nyplatonsk politisk filosofi med to observasjoner. Ikke bare i platonismen i antikken, men også i andre filosofiske skoler ser vi to slags holdninger til filosofiens forhold til samfunnet og det politiske liv. På den ene siden vektlegger alle filosofiske skoler at filosofen bør perfeksjonere seg selv. Noen av dem, epikureerne for eksempel, mente at denne oppgaven er

\footnotetext{
${ }^{65}$ O’Meara, ibid., 121.

${ }^{66}$ Evnapios, Hist. Fr. 23.

${ }^{67}$ Themistios var som Julian en hedensk platoniker, mest kjent for sine kommentarer på Aristoteles' verker. Han avvek allikevel fra hovedtradisjonen fra Plotin og Jamblikk. Themistios' brev til Julian er ikke bevart men innholdet er temmelig klart fra Julians svar.

${ }^{68}$ Se Athanassiadi, ibid., s. 56-57 og Julian, Til Themistios filosofen 264b-c.
} 
uforenelig med politisk virksomhet, at filosofen burde holde seg unna politikk. For andre var forholdet mer komplekst. Selv om vi kan se tendenser hos platonikere, aristotelikere og stoikerne til å isolere filosofen fra samfunnet, hadde alle disse skoler teorier, mer eller mindre idealistiske, om samfunnet. Det blir da nærliggende å mene at filosofen har noe å bidra med i samfunnssaker, til og med kanskje en plikt til å bidra. Nyplatonismen kjennetegnes av samme slags tvetydige forhold til den politiske sfære. Hos Plotin er det individets fullkommenhet som trekkes frem som filosofiens hovedoppgave, selv om vi også hos ham kan se spor av en samfunnsrolle for filosofien. De senere nyplatonikere var mer politisk engasjert og sluttet seg helt til ideen om at filosofen har en rolle i samfunnet, men heller ikke de etterlot seg vesentlige originale verker som kan beskrives som politisk filosofi. Ifølge dem hadde Platon og Aristoteles allerede sagt det som sies burde om slike saker.

Den andre observasjonen er at på tross av manglende originalitet angående politisk filosofi hadde disse filosofene en høy samfunnsstatus, og utdanningen de tilbød, var nærmest ensbetydende med høyere utdanning i Romerriket i senantikken, noe tilsvarende universitetsutdanning i våre dager. Det er vanskelig å bedømme i hvilken grad deres undervisning fikk utslag i studentenes politiske virke og dermed ute i samfunnet, men det må antas å være ikke ubetydelig. Faktisk har filosofer sjelden hvis noen sinne i Vestens historie hatt lettere tilgang til den politiske makten som lærere, embetsmenn, rådgivere og i Julians tilfelle som keiser og pontifex maximus. Julians sosiale og religiøse reformer ble visst nok avbrutt. Mye tyder imidlertid på at noe av hans filosofisk motiverte ideer om samfunnets maktstruktur samfunnet som et mikrokosmisk bilde av universet og filosofens/prestens barmhjertige handlinger som imitasjon av gudenes filantropiske forsyn - overlevde hos hans hovedmotstander, den kristne kirke, så vel som hos islamske filosofer og herskere som noe senere overtok store deler av Romerriket. 